\title{
Perforated Stomach Ulcer on the Background of Her Bleeding
}

\author{
Shaposhnikov Veniamin Ivanovich* \\ Kuban Medical Institute, Russia
}

Submission: December 1, 2018; Published: January 11, 2019

"Corresponding author: Shaposhnikov Veniamin Ivanovich, Professor of surgical diseases, Kuban Medical Institute, Noncommercial educational private institution of higher education, Vice Rector, 350072, St. 40 let pobedy sq 33/8 193, Krasnodar, Russia

\begin{abstract}
The author describes the kazuisticheskih observation, when the patients at the same time, there have been three complications (penetration, hemorrhage and perforation) gastric ulcers. Internal bleeding in the abdomen accompanied by formation of hemosiderin, which led to a change in color of the peritoneum. Gastrectomy was performed in a patient, which gave a positive result.
\end{abstract}

Keywords: Stomach ulcers; Kazuisticheskih; Abnormal operation; Gastric ulcers; Internal bleeding

\section{The Purpose of Isslevovanijaj}

Provide international medical community kazuisticheskih monitor complicated stomach ulcer.

\section{Introduction}

Treatment of uncomplicated ulcers is the prerogative of the therapists and represents a three-way acid suppressant activity of cells of the stomach and Helicobacter pylori aggression [1-3]. Therapy the same complicated ulcers sometimes require surgical correction hearth ulcerative lesions of the body wall. At this time in the abdominal cavity may experience different pathological processes, and then experience the surgeon becomes the leading value in the outcome of treatment [4-6]. However, not only in surgical tactics, but conservative treatment and aftercare, have a lot of uncertainties that affect the outcome of the operation of a patient [3-5]. If the met technical process, in selecting the operational benefits of paramount importance to the already existing international surgical experience that allows you to make a reasonably correct decision in carrying out an operation [7].

\section{Materials and Methods}

For 60 years, the surgical activity in various medical institutions of RUSSIA, Ukraine and Kazakhstan I personally operated on more than a thousand patients with complicated ulcers of the stomach and duodenum. They were bleeding and perforation, penetration, but only once all of these three types of complications accompanied by external and internal bleeding from severe imbibirovaniem gemosiderinom parietal and visceral peritoneum. This observation can be rightfully classified as jargon, because similar observations in the medical literature, I have not met [8].

Male 54 years was taken from home with severe abdominal pain. Several times was vomiting coffee grounds. More than 10 years history of ulcerative. He was treated with home remedies (baking soda, mineral water, alkaline diet, small doses of alcohol, Almagell etc.). In the process of life obsledovalsja radio graphically and endoscopic ally and knew about yourself stomach ulcers. Suggested surgery, but he refused from it. Relapses of the disease originated from a week ago and started with amplify pain in epigastralna area, heartburn and other diarrheal events. Before entering the hospital there, was a bloody vomiting, which suddenly ended unbearable abdominal pain? In a survey in the reception Department of the patient identified bright signs of peritonitis and he was taken to the operating room.

After you perform a typical up-front manipulation on correction of homeostasis and to determine acceptability of surgical operation was carried out aggression. It was carried out under general anesthetic endotraheal nymr. In the abdominal cavity was found up to 1.5 liters of fluid is black, while the parietal and visceral peritoneum in all departments was a gatovogo color. After the initial sanitation of the abdominal cavity in piloricheskom Division stomach detected dense ulcerative $8 \mathrm{~h} 6 \mathrm{sm}$ size infiltration. Closer to a small curvature had performative bore size to $0.5 \times 0.5 \mathrm{~cm}$. Remove stiff ulcerative substrate without leaving the bottom of ulcers. The patient was 
carried out with total gastrectomy anastomosis type end-to-side between the lower third of the esophagus and a loop of the small intestine. Additionally, seized entero-entero anastomosis with a stub to Give the leading colon. Abdomen drained.

\section{Resultants}

Complications were observed. In macroscopical study remote drug detected kalljoznaja krateroobraznaja ulcer size from the mucous membranes of $2.5 \times 2.5 \mathrm{~cm}$. In the area of its perimeter was a blood vessel size $0.1 \times 0.1 \mathrm{~cm}$. Histological study of the cancerous tissue is not detected-rough had scar tissue. The patient was discharged through 17 days after the operation. Follow through 6 months showed that he had begun to work (he was by profession a school teacher).

\section{Discussion}

Anamnesis and operating of the finds suggest that patient for a long time suffered from stomach ulcers. Treatment was carried out not at the present level, which led to the formation of giant kalleznoj sores, which initially complicated penetration and then bleeding. In the development of the perforation, in addition to the acidic activity of cells of the stomach, and Helicobacter pylori. Internal bleeding with expiration of hydrochloric acid into the abdominal cavity in this patient continued several days. This led to the breakdown of hemoglobin with the formation of hemosiderin, which came not only in this cavity, but has soaked into the peritoneum. In his clinical practice such observations I no longer met. It is not excluded that other surgeons also observed a similar complication and then it will be possible to draw certain conclusions. One thing is clear that gastric ulcer requires three therapies.

\section{Conclusion}

Depending on the treatment of gastric ulcers can develop giant kalleznaja ulcers, which can lead to not only the penetration and bleeding but punching in the free abdomen. Bleeding can be both external and internal. When you hit the same hydrochloric acid together with blood in the abdominal cavity is accompanied by formation of hemosiderin, which impregnates the peritoneum, giving it a black color.

\section{References}

1. Vasilyev JV (2002) Gastric ulcer disease hospital of stomach and duodenal ulcers, abnormal bleeding and Helicobacter pylori. Consilium medicum 3: 6-11.

2. May IV, Samsonov AA (2004) Duodenal ulcer: different approaches to contemporary conservative therapy. Consilium medicum 1: 6-11.

3. Saveliev VS (2008) Guide for emergency surgery the abdominal organs. Bleeding from the upper gastrointestinal tract. pp. 526-526.

4. Kubyshkin VA, Shishin KV (2004) Erosive-ulcerous lesion of upper gastrointestinal tract in the early postoperative period. Consilium medicum Surgery 1: 29-31.

5. Bone RC (1996) Immunologic dissonance: a continuing evolution in our understanding of the systemic inflammatory response syndrome (SIRS) and the multiple organ dysfunction syndromes (MODS). ANN intern Med 125(8): 680-687.

6. Wang P, Chaudri IH (1991) Crystalloid resuscitation restores but does not maintain cardiac output following severe hemorrhage. J Surg Res 50(2): 163-169.

7. Shaposhnikov VI (2018) Associated complications giant stomach ulcers. Scientific articles collection of the $35^{\text {th }}$ International Scientific Conference of Eurasian Scientific Association, Moscow, ESA, pp. 234.

8. Kuznetsov NA (2003) Modern technologies of treatment of acute blood loss. Consilium medicum 6: 347-357.

\section{Your next submission with JuniperPublishers} will reach you the below assets

- Quality Editorial service

- Swift Peer Review

- Reprints availability

- E-prints Service

- Manuscript Podcast for convenient understanding

- Global attainment for your research

- Manuscript accessibility in different formats ( Pdf, E-pub, Full Text, audio)

- Unceasing customer service

Track the below URL for one-step submission https://juniperpublishers.com/online-submission.php 